\title{
The genetic basis of colonic adenomatous polyposis syndromes
}

Bente A. Talseth-Palmer 1,2,3,4,5

\begin{abstract}
Colorectal cancer (CRC) is one of the most common forms of cancer worldwide and familial adenomatous polyposis (FAP) accounts for approximately $1 \%$ of all CRCs. Adenomatous polyposis syndromes can be divided into; familial adenomatous polyposis (FAP) - classic FAP and attenuated familial adenomatous polyposis (AFAP), MUTYHassociated polyposis (MAP), NTHL1-associated polyposis (NAP) and polymerase proofreading-associated polyposis (PPAP). The polyposis syndromes genetics and clinical manifestation of disease varies and cases with clinical diagnosis of FAP might molecularly show a different diagnosis.

This review examines different aspects of the adenomatous polyposis syndromes genetics and clinical manifestation of disease; in addition the genotype-phenotype and modifier alleles of FAP will be discussed. New technology has made it possible to diagnose some of the APC mutation negative patients into their respective syndromes. There still remain many molecularly undiagnosed adenomatous polyposis patients indicating that there remain causative genes to be discovered and with today's technology these are expected to be identified in the near future. The knowledge about the role of modifier alleles in FAP will contribute to improved pre-symptomatic diagnosis and treatment.

New novel mutations will continually be discovered in genes already associated with disease and new genes will be discovered that are associated with adenomatous polyposis. The search for modifier alleles in FAP should be made a priority.
\end{abstract}

Keywords: Genetics, FAP, Genotype-phenotype, Modifier genes, MAP, NAP, PPAP

\section{Background}

Colorectal cancer (CRC) is one of the most common form of cancer worldwide [1]. CRC development is considered to be a result of a combination of genetic and environmental factors and it is estimated that up to $35 \%$ of all CRCs are associated with a genetic predisposition [2]. Familial adenomatous polyposis (FAP) accounts for approximately $1 \%$ of all CRCs [3] and is an autosomal dominantly inherited condition where affected individuals develop hundreds to thousands of adenomas (polyposis) throughout the colon and rectum at unusually young ages. The disease is due to mutations in the adenomatous polyposis coli $(A P C)$ gene. If left untreated (if the colon is not removed), one or more of these adenomas invariably become malignant with almost $100 \%$ penetrance. Although

\footnotetext{
Correspondence: Bente.Talseth-Palmer@ntnu.no
}

'Department of Laboratory Medicine, Children's and Women's Health, Faculty of Medicine and Health Sciences, Norwegian University of Science and Technology, Trondheim 7491, Norway

${ }^{2}$ Clinic for Medicine, Møre og Romsdal Hospital Trust, Molde, Norway

Full list of author information is available at the end of the article prophylactic surgery significantly reduces the mortality associated with FAP, extra-colonic manifestations of the disease are now more clinically relevant, most notably desmoid tumours, which are hard to treat and a major cause of death $[4,5]$. Attenuated FAP (AFAP) is a milder form of classic FAP with less polyps $(<100)$ and a later age of polyp/cancer onset.

Herein an update on the genetic basis of FAP and other adenomatous polyposis syndromes (MAP, NAP and PPAP) is discussed. This review focuses on the genetics of FAP, the genetic phenotypes of the disease (genotype-phenotype correlations) and studies on modifier alleles. It also gives an update on other adenomatous polyposis syndromes. Recent findings are highlighted and gaps are identified in current literature, and consideration is give as to how these may be addressed through genomic approaches. A summary of the different adenomatous polyposis syndromes is shown in Table 1. 
Table 1 Summary of adenomatous polyposis syndrome genetics, inheritance and clinical manifestation

\begin{tabular}{|c|c|c|c|c|}
\hline Name & Abbreviation & Genetics & Inheritance & Clinical manifestation \\
\hline $\begin{array}{l}\text { Classical familial } \\
\text { adenomatous } \\
\text { polyposis }\end{array}$ & FAP & Germline APC mutations & $\begin{array}{l}\text { Autosomal } \\
\text { dominant }\end{array}$ & $\begin{array}{l}\text { 100-1000s colorectal polyps which manifests at age; early } \\
\text { childhood-mid 30s (typically 16) and rapidly increasing. Almost } \\
100 \% \text { risk of CRC if left untreated. } \\
\text { Treatment recommendations, colectomy after adenomas emerges. } \\
\text { Associated with adenomatous polyps colon, CRC, fundic gland } \\
\text { polyps, adenomatous polyps in the duodenum and periampullary } \\
\text { region, extra intestinal lesions (fibromas, lipomas, sebaceous and } \\
\text { epidermoid cysts = Gardner syndrome), desmoid tumours (benign } \\
\text { soft-tissue tumours), congenital hypertrophy of the retinal pigment } \\
\text { epithelium (CHRPE), and cancers of the brain (medulloblastoma = } \\
\text { Turcot syndrome), pancreas, thyroid, gall bladder, bile duct and ad- } \\
\text { renal gland. }\end{array}$ \\
\hline
\end{tabular}

Attenuated familial AFAP Germline APC mutations

polyposis adenomatous

\begin{abstract}
Autosomal $<100$ colorectal polyps (typically 30 ) at age typically between 40 dominant and 70 years (average 55). Estimated $70 \%$ CRC risk by age 80 years.

Treatment recommendations, colectomy may be necessary but for some polyps are limited enough in number that surveillance of colon is sufficient.

Associated with adenomatous polyps of the colon, CRC, upper gastrointestinal polyps, duodenal and gastric adenomas and fundic glad polyps. In addition, hepatoblastoma, gastric and breast adenocarcinoma have been documented.
\end{abstract}

$\begin{array}{ll}\begin{array}{l}\text { MUTYH associated } \\ \text { polyposis }\end{array} & \text { MAP } \\ \text { mutations }\end{array}$

NTHL1 associated NAP polyposis
Germline homozygous or compound heterozygous NTHL1 mutations

Germline POLE or POLD1 mutations
Autosomal recessive

Usually $<100$ polyps at average age of mid-50s and give a high risk of CRC.

Associated with malignancies of the duodenum, ovary, bladder and skin.

Autosomal Polyp number unknown as it is a recently discovered association recessive but an extended spectrum of cancer diagnosis has been observed (CRC, endometrium, duodenum, skin, breast, pancreatic and others)

Multiple primary tumours in all patients.

Autosomal Polyp number unknown, also recently discovered. dominant Associated with multi-tumour phenotypes like colon/pancreas/ ovaries/small intestine and colon/ovarian/endometrial/brain.

\section{Familial Adenomatous Polyposis (FAP) genetics}

FAP is a result of germline mutations in $A P C[6,7]$. $A P C$ is a tumour suppressor gene that plays a central role in the Wnt signalling pathway. A detailed review of $A P C$ structure and function has been published by Half et al. [8]. In brief, $A P C$ is located on locus 5q21-22, consists of 15 coding exons (number of exons have increased to 18 after the identification of two promoter regions of $A P C$ [9]) and is $8532 \mathrm{bp}$ in size which translates to a protein comprising 2843 amino acids [10]. Somatic mutations in $A P C$ is also a key molecular event in sporadic colorectal cancer present in about $80 \%$ of patients [10]. Two codons (1061 and 1309) are mutational hot-spots and account for 11 and $17 \%$ of all germline mutations, respectively [11] and are common sites of somatic change in sporadic CRC. But in a number of patients no underlying germline mutation can be identified $[12,13]$.

$A P C$ plays a central role in the Wnt-signalling pathway, especially in regards to the degradation of $\beta$-catenin within the cell cytoplasm. If $A P C$ is mutated, the $\beta$ -
catenin-Tcf complex is not suppressed and leads to constitutive activation of several genes and oncogenes controlling cell growth and division [10]. Mutations in APC affect the ability of the cell to maintain normal growth and function, which results in cell overgrowth/adenoma formation.

About 25\% of people with FAP do not have any family history of disease and harbour a de novo mutation in $A P C$ without any clinical or genetic evidence of FAP in the family [14-16]. One study suggests that a $5 \mathrm{bp}$ deletion of codon 1309 (c.3927_3931del) is overrepresented in patients with a suspected de novo mutations (29\%) and in proven de novo mutation carriers (45\%) [17], supporting the view of codon 1309 as a hotspot for mutations.

New methods that can screen genomic loci at great depths are revealing that patients that were thought to be $A P C$ mutation negative have pathogenic germline heterozygous $A P C$ mutations [18], $A P C$ promoter mutations [9], deep intronic mutations [19], complex genomic rearrangements [20], somatic mutations or $A P C$ mutation mosaicism [12, 21-23]. 


\section{Classic FAP}

Classic FAP (OMIM \#175100) refers to patients who are diagnosed with FAP due to the development of more than 100 adenomatous colorectal polyps from early childhood (typically at age 16) who harbour an $A P C$ germline mutation. On average, cancer develops a decade after the appearance of adenomas and if the colon is left untreated most patients develop CRC by 40 years of age [8]. Other gastrointestinal manifestations include fundic gland polyps (which occurs in approximately $90 \%$ of FAP patients and are mostly benign [24]), adenomatous polyps in the duodenum and periampullary region (lifetime risk has been reported to reach $100 \%[25,26]$ ), and small bowel adenomas [8]. Extra-colonic manifestations are common but rarely malignant and include [8]; desmoid tumours (benign soft-tissue tumours that can be fatal due to progressive invasion into surrounding tissues [5, 27]), cutaneous lesions such as fibromas, lipomas, sebaceous and epidermoid cysts (present in Gardner syndrome [28], a phenotypic variant of FAP), congenital hypertrophy of the retinal pigment epithelium (CHRPE, which is a lesion causing discoloration in the ocular fundus - low-grade adenocarcinoma has been described in these lesions [29]), brain tumours (mainly medulloblastoma, described in Turcot's syndrome, another phenotypic variant of FAP), hepatoblastoma, dental abnormalities, cancer of the pancreas, thyroid, gallbladder, bile duct and adrenal glands [8, 30-32].

\section{Attenuated familial adenomatous polyposis (AFAP)}

AFAP is a phenotypic variant of FAP; patients develop less than 100 polyps, delayed polyp growth and later age of cancer onset. Germline APC mutations are also present in these patients, which are mainly observed in three sections of the gene (first 5 exons, exon 9 and in the distal 3'end of $A P C$ ) [33]. Mean age of polyp diagnosis in AFAP patients is variable but on average in fourth to fifth decade of life, with cancer developing 10-15 years later $[8,34]$. Screening is suggested to start late teens to mid-20s [34]. As with FAP the most common extra-colonic manifestations are upper gastrointestinal polyps, duodenal and gastric adenomas and fundic gland polyps [33]. Extra-colonic manifestations in AFAP are rare but hepatoblastoma, gastric and breast adenocarcinoma have been documented $[8,33]$.

\section{FAP genotype-phenotype}

In families with FAP, considerable variability in disease expression is observed within and between families harbouring identical $A P C$ mutations [13, 35-37] and it has been shown that the greater the number of colorectal adenomas, the greater the risk of CRC [38]. It has been demonstrated that there is significant variation with respect to age of onset of intestinal symptoms and the development of CRC, even in patients with the same mutations [13]. Haplotype reconstruction from pedigrees have revealed there is no evidence for a specific $A P C$ haplotype associated with disease severity [39]. Genotype-phenotype correlations have been associated with the location of germline mutations within $A P C$ that are related to disease severity and the expression of extra-colonic disease [40-42], see figures in Half et al. [8] and Macrae [10]. Patients with mutations in the mutation cluster region (MCR), located between codons 1286 and 1513 [43], have generally a worse prognosis with earlier disease onset than those with mutations outside this region [44]. Germline mutations at codon 1309 is associated with most severe disease [45], while milder forms with less than 100 adenomas and later ages of onset (AFAP) are associated with codons <157, 312-412 and >1595 [33, 41]. CHRPE has been associated with mutations between codons 457 and 1444 and susceptibility to desmoid tumours is correlated with mutations between codons 1395 and 2000, with slight variability in codon ranges between reports $[8,10,46]$. There is evidence of large phenotypic variation among patients with identical germline mutations [13], strongly suggesting the existence of FAP modifier alleles.

\section{FAP modifier alleles}

The phenotypic variation of $A P C^{M i n}$ mouse model of FAP reveal among different inbred strains the importance of modifier alleles [47]. There is evidence to suggest that these phenotypic differences are caused by segregating modifier alleles that impact adenoma number [47]. Several have been found in the min mouse model. The best known modifier is possibly Mom1 (modifier of Min 1), which is semi-dominant - each copy affects tumour multiplicity by a factor of approximately 2 [47]. Pla2g2a (found at the same region as Mom1) has also been shown to affect the net growth rate of adjacent tumours [48]. The exact mechanism by which it influences tumorigenesis remains unresolved [47] and the effort of linking PLA2G2A to FAP in humans has failed $[49,50]$, illustrating the difficult task of searching for modifier alleles in FAP. Many different genetic modifiers of the Apc knockout mouse models have been found, affecting karyotypic stability, DNA mutation rate, recombination rates, differentiation, DNA methylation, stromal regulation, cell growth and proliferation (reviewed in $[47,51])$. There are claims that mouse models are essential in identifying modifiers of human disease and by using an Apc $(\mathrm{Min} /+)$ model have identified seven genes that are the most likely candidates for the Mom5 modifier [52]. Recently it has been reported that a new Xenopus tumour model might be especially useful for identifying or characterising modifier genes associated with $A P C$ mediated tumour formation [53]. 
Genome wide association studies (GWASs) have identified approximately 40 CRC susceptibility loci, where each loci gives a small increased risk of CRC [54]. The risk associated with each variant is too small on their own for translation to testing in clinical practice but the development of algorithms estimating cumulative risk are expected to lead to clinical application [54]. Two of these SNPs have been associated with Lynch syndrome $[55,56]$ and recently the same SNPs (rs16892766 and rs3802842) have been associated with adenoma number in $A P C$ mutation carriers causing a more sever FAP phenotype [57].

Several studies suggest that low-penetrant susceptibility genes may play an important role in the development of sporadic CRC [58-63]. There is evidence to show that the variation in FAP severity (which have been shown to be independent of $A P C$ mutations and most likely the action of modifier alleles), is expected to result in different rates of adenoma number rather than differences in tumour progression [64]. Modifier genes can influence individual susceptibility to cancer by enhancing or suppressing disease initiation, growth and/or progression. The pattern of intra-familial variation in colonic FAP severity is consistent with the action of modifier genes [39, 64-66]. As described above there is plenty of evidence from animal models for the existence of FAP modifiers and knowledge of modifier genes will contribute to better prophylactic measures for FAP patients [67]. It is important that the search for modifier genes/alleles continues.

\section{Other adenomatous polyposis syndromes}

Some of the recently discovered adenomatous polyposis syndromes are recessively inherited and present a diagnostic challenge. Individually, the other polyposis syndromes are very rare and may show overlapping phenotypes.

\section{MUTYH-associated polyposis (MAP)}

MAP (OMIM \#608456) is an autosomal recessive disease caused by biallelic mutations in the base excision repair gene MUTYH. MUTYH is involved in base excision repair and is necessary in the amelioration of reactive oxygen species DNA damage prior to cell division [68]. In a recent study, $23 \%$ of $A P C$ mutation negative samples (FAP samples screened for APC mutations) were found to harbour pathogenic mutations in $M U T Y H$ [69]. Patients usually present with $<100$ colorectal polyps at an average age of disease diagnosis at around 50 years of age (which is similar to AFAP) and a high risk of CRC $[69,70]$. The age of onset of polyposis has been shown to be significantly delayed for biallelic $M U T Y H$ carriers compared to APC mutation carriers [69]. MAP has been associated with malignancies of the duodenum, ovaries, urinary bladder and skin-occasionally resembling the phenotype of LS [71]. In a recent report describing extra-colonic disease, biallelic carriers are at high risk of urinary bladder and ovarian cancer, while there is some evidence that monoallelic carriers are at risk of gastric, hepatobiliary, endometrial and breast cancer [72]. No increased risk of other extra-colonic cancers associated with FAP was observed in this study [72].

\section{NTHL1-associated polyposis (NAP)}

A recently described autosomal recessive polyposis condition has been named NAP (OMIM \#616415). Patients have germline homozygous or compound heterozygous mutations in the base excision repair gene NTHL1 [73]. Due to its recent discovery the clinical manifestation is not set, but it points towards an extended spectrum of cancer diagnosis in these patients; endometrial, duodenal, skin (basal cell carcinoma) and others [74]. Given such disease heterogeneity, Dutch researchers suggest it is a novel cancer syndrome. This is supported by Canadian researchers who also identified biallelic NTHL1 mutations in a woman with multiple primary tumours [75].

\section{Polymerase proofreading-associated polyposis (PPAP)}

PPAP is associated with mono- and biallelic mutations in the genes POLE and POLD1 [76], both genes a part of the mismatch repair (MMR) pathway. PPAP is in an autosomal dominantly inherited CRC predisposition [77]. Variants in POLE and POLD1 are known to increase the somatic mutation rate in tumours [78], thereby increasing the risk of tumour development. The somatic mutation landscape can display great diversity [79], which could be a reason for the differences observed in the location of primary tumours between patients. Both POLE and POLD1 have been associated with an increased risk of endometrial cancer [76, 80]. POLD1 has been associated with breast and brain tumours in addition to CRC and endometrial cancer [81]. Multitumour phenotypes such as colon/pancreas/ovaries/ small intestine [82] and colon/ovarian/endometrial/brain [80] have been seen in POLE mutation carriers. In addition, $P O L E$ has been linked to an early onset cancer case raising the question whether this specific POLE mutation may confer a more severe phenotype than previously reported POLE/POLD1 mutations [83].

\section{Conclusions}

Genetic testing has rapidly grown in the last few years with the advancement of next-generation sequencing technologies. Targeted testing of all polyposis patients with a gene-panel can now be performed at reasonable cost such that targeted screening or prophylactic surgery can be offered to patients with a molecular diagnosis of polyposis.

In 2009 Half et al. [8] identified unresolved questions regarding FAP, one being that there are many FAP 
patients who do not get a molecular diagnosis. Since 2009, three additional genes have been associated with adenomatous polyposis, one being NTHL1 which has been classified as NAP, and POLE and POLD1 which has been classified as PPAP.

New novel mutations will continually be discovered in genes already associated with disease and new genes will be discovered that are associated with adenomatous polyposis. Exome sequencing has already been used to identify new candidate genes; PIEZ01 and ZSWiM7 [84], which are currently subject to further investigation.

A recent study has found that gene expression of $A P C$ was reduced in FAP patients without germline APC mutations [85]. An explanation may lie in differential epigenetic factors that contribute to the lack of gene expression in these patients, maybe more focus should be placed on understanding the role of epigenetics in polyposis syndromes.

There remain a high proportion of $A P C$ mutation negative patients even after extensive searches for new causative genes. The question remains, have we just missed them, or is it that these patients harbour rare alleles that await discovery. Diagnostics laboratories around the world are spending considerable amounts of time designing gene-panels to test for all adenomatous polyposis syndromes using new sequencing technology such that in the near future the number of $A P C$ mutation negative patients is expected to significantly decrease. Until then, re-testing "old" APC mutation negative patients for additional genes that have already been identified should be of special interest.

\section{Acknowledgment}

Thank you to Professor Rodney J. Scott for helping with the editing of the final draft of the manuscript.

\section{Funding}

This work was supported by the Liaison Committee between the Central Norway Regional Health Authority (RHA) and the Norwegian University of Science and Technology (NTNU), Norway; Møre og Romsdal Hospital Trust, Norway; and the Cancer Institute NSW, Australia.

\section{Availability of data and materials}

Data sharing not applicable to this article as no datasets were generated or analysed during the current study.

\section{Author's contributions}

BTP has reviewed the literature and written the review.

\section{Competing interests}

The author declares that she has no competing interest.

\section{Consent for publication}

Not applicable.

Ethics approval and consent to participate

Not applicable.

\section{Publisher's Note}

Springer Nature remains neutral with regard to jurisdictional claims in published maps and institutional affiliations.

\section{Author details}

'Department of Laboratory Medicine, Children's and Women's Health, Faculty of Medicine and Health Sciences, Norwegian University of Science and Technology, Trondheim 7491, Norway. ${ }^{2}$ Clinic for Medicine, Møre og Romsdal Hospital Trust, Molde, Norway. ${ }^{3}$ School of Biomedical Sciences and Pharmacy, Faculty of Health and Medicine, University of Newcastle, Newcastle, NSW, Australia. ${ }^{4}$ Hunter Medical Research Institute, Newcastle, NSW, Australia. ${ }^{5}$ Clinic for Medicine, Library, Molde Hospital, Parkvegen 84 , Molde 6407, Norway.

Received: 18 March 2016 Accepted: 7 March 2017

Published online: 16 March 2017

References

1. Siegel RL, Miller KD, Jemal A. Cancer statistics, 2015. CA Cancer J Clin. 2015; 65(1):5-29. doi:10.3322/caac.21254.

2. Davidson NO. Genetic testing in colorectal cancer: who, when, how and why. Keio J Med. 2007;56(1):14-20.

3. Fearnhead NS, Britton MP, Bodmer WF. The ABC of APC. Hum Mol Genet. 2001;10(7):721-33.

4. Clark SK, Phillips RK. Desmoids in familial adenomatous polyposis. Br J Surg. 1996;83(11):1494-504.

5. Sturt NJ, Clark SK. Current ideas in desmoid tumours. Fam Cancer. 2006;5(3): 275-85. doi:10.1007/s10689-005-5675-1. discussion 87-8.

6. Groden J, Thliveris A, Samowitz W, Carlson M, Gelbert L, Albertsen H, et al. Identification and characterization of the familial adenomatous polyposis coli gene. Cell. 1991;66(3):589-600.

7. Kinzler KW, Nilbert MC, Su LK, Vogelstein B, Bryan TM, Levy DB, et al. Identification of FAP locus genes from chromosome 5q21. Science. 1991; 253(5020):661-5.

8. Half E, Bercovich D, Rozen P. Familial adenomatous polyposis. Orphanet J Rare Dis. 2009;4:22. doi:10.1186/1750-1172-4-22.

9. Rohlin A, Engwall Y, Fritzell K, Goransson K, Bergsten A, Einbeigi Z, et al. Inactivation of promoter 1B of APC causes partial gene silencing: evidence for a significant role of the promoter in regulation and causative of familial adenomatous polyposis. Oncogene. 2011;30(50):4977-89. doi:10.1038/onc. 2011.201.

10. Macrae F, du Sart D, Nasioulas S. Familial adenomatous polyposis. Best Pract Res Clin Gastroenterol. 2009;23(2):197-207. doi:10.1016/j.bpg.2009.02.010.

11. Jass JR. Colorectal polyposes: from phenotype to diagnosis. Pathol Res Pract. 2008;204(7):431-47. doi:10.1016/j.prp.2008.03.008.

12. Spier I, Drichel D, Kerick M, Kirfel J, Horpaopan S, Laner A et al. Low-level APC mutational mosaicism is the underlying cause in a substantial fraction of unexplained colorectal adenomatous polyposis cases. J Med Genet. 2015. doi:10.1136/jmedgenet-2015-103468.

13. Friedl W, Caspari R, Sengteller M, Uhlhaas S, Lamberti C, Jungck M, et al. Can APC mutation analysis contribute to therapeutic decisions in familial adenomatous polyposis? Experience from 680 FAP families. Gut. 2001:48(4):515-21.

14. Gayther SA, Wells D, SenGupta SB, Chapman P, Neale K, Tsioupra K, et al. Regionally clustered APC mutations are associated with a severe phenotype and occur at a high frequency in new mutation cases of adenomatous polyposis coli. Hum Mol Genet. 1994;3(1):53-6.

15. Bisgaard ML, Fenger K, Bulow S, Niebuhr E, Mohr J. Familial adenomatous polyposis (FAP): frequency, penetrance, and mutation rate. Hum Mutat. 1994;3(2):121-5. doi:10.1002/humu.1380030206.

16. Zhang Y, Lu G, Hu Q, Wang X, Li C, Mao Y, et al. A de novo germline mutation of APC for inheritable colon cancer in a Chinese family using multigene next generation sequencing. Biochem Biophys Res Commun. 2014:447(3):503-7. doi:10.1016/j.bbrc.2014.04.014

17. Aretz S, Uhlhaas S, Caspari R, Mangold E, Pagenstecher C, Propping P, et al. Frequency and parental origin of de novo APC mutations in familial adenomatous polyposis. Eur J Hum Genet. 2004;12(1):52-8. doi:10.1038/sj. ejhg.5201088.

18. Out AA, van Minderhout IJ, van der Stoep N, van Bommel LS, Kluijt I, Aalfs C, et al. High-resolution melting (HRM) re-analysis of a polyposis patients cohort reveals previously undetected heterozygous and mosaic APC gene mutations. Fam Cancer. 2015;14(2):247-57. doi:10.1007/s10689-015-9780-5.

19. Spier I, Horpaopan S, Vogt S, Uhlhaas S, Morak M, Stienen D, et al. Deep intronic APC mutations explain a substantial proportion of patients with familial or early-onset adenomatous polyposis. Hum Mutat. 2012;33(7):104550. doi:10.1002/humu.22082. 
20. Charames GS, Ramyar L, Mitri A, Berk T, Cheng H, Jung J, et al. A large novel deletion in the APC promoter region causes gene silencing and leads to classical familial adenomatous polyposis in a Manitoba Mennonite kindred. Hum Genet. 2008;124(5):535-41. doi:10.1007/s00439-008-0579-4.

21. Hes FJ, Nielsen M, Bik EC, Konvalinka D, Wijnen JT, Bakker E, et al. Somatic APC mosaicism: an underestimated cause of polyposis coli. Gut. 2008;57(1): 71-6. doi:10.1136/gut.2006.117796.

22. Aretz S, Stienen D, Friedrichs N, Stemmler S, Uhlhaas S, Rahner N, et al. Somatic APC mosaicism: a frequent cause of familial adenomatous polyposis (FAP). Hum Mutat. 2007;28(10):985-92. doi:10.1002/humu.20549.

23. Yamaguchi K, Komura M, Yamaguchi R, Imoto S, Shimizu E, Kasuya S, et al. Detection of APC mosaicism by next-generation sequencing in an FAP patient. J Hum Genet. 2015;60(5):227-31. doi:10.1038/jhg.2015.14.

24. Bianchi LK, Burke CA, Bennett AE, Lopez R, Hasson H, Church JM. Fundic gland polyp dysplasia is common in familial adenomatous polyposis. Clin Gastroenterol Hepatol. 2008;6(2):180-5. doi:10.1016/j.cgh.2007.11.018.

25. Bulow S, Bjork J, Christensen IJ, Fausa O, Jarvinen H, Moesgaard F, et al. Duodenal adenomatosis in familial adenomatous polyposis. Gut. 2004;53(3): 381-6.

26. Heiskanen I, Kellokumpu I, Jarvinen H. Management of duodenal adenomas in 98 patients with familial adenomatous polyposis. Endoscopy. 1999;31(6): 412-6. doi:10.1055/s-1999-41.

27. Soravia C, Berk T, McLeod RS, Cohen Z. Desmoid disease in patients with familial adenomatous polyposis. Dis Colon Rectum. 2000;43(3):363-9.

28. Juhn E, Khachemoune A. Gardner syndrome: skin manifestations, differential diagnosis and management. Am J Clin Dermatol. 2010;11(2):117-22. doi:10. 2165/11311180-000000000-00000.

29. Shields JA, Shields CL, Eagle Jr RC, Singh AD. Adenocarcinoma arising from congenital hypertrophy of retinal pigment epithelium. Arch Ophthalmol. 2001;119(4):597-602

30. Nilbert M, Kristoffersson U, Ericsson M, Johannsson O, Rambech E, Mangell P. Broad phenotypic spectrum in familial adenomatous polyposis; from early onset and severe phenotypes to late onset of attenuated polyposis with the first manifestation at age 72. BMC Med Genet. 2008;9:101. doi:10.1186/ 1471-2350-9-101.

31. Boger C, Haag J, Egberts JH, Rocken C. Complex APC germline mutation associated metaplasia and intraepithelial neoplasia (CAM-IEN) of the gallbladder. Pathol Res Pract. 2016;212(1):54-8. doi:10.1016/j.prp.2015.11.010.

32. Galiatsatos P, Foulkes WD. Familial adenomatous polyposis. Am J Gastroenterol. 2006;101(2):385-98. doi:10.1111/j.1572-0241.2006.00375.x.

33. Knudsen AL, Bisgaard ML, Bulow S. Attenuated familial adenomatous polyposis (AFAP). A review of the literature. Fam Cancer. 2003;2(1):43-55

34. Syngal S, Brand RE, Church JM, Giardiello FM, Hampel HL, Burt RW, et al. ACG clinical guideline: Genetic testing and management of hereditary gastrointestinal cancer syndromes. Am J Gastroenterol. 2015;110(2):223-62. doi:10.1038/ajg.2014.435. quiz 63.

35. Giardiello FM, Krush AJ, Petersen GM, Booker SV, Kerr M, Tong LL, et al. Phenotypic variability of familial adenomatous polyposis in 11 unrelated families with identical APC gene mutation. Gastroenterology. 1994;106(6):1542-7.

36. Brensinger JD, Laken SJ, Luce MC, Powell SM, Vance GH, Ahnen DJ, et al. Variable phenotype of familial adenomatous polyposis in pedigrees with 3' mutation in the APC gene. Gut. 1998;43(4):548-52.

37. Scott RJ, van der Luijt R, Spycher M, Mary JL, Muller A, Hoppeler T, et al. Novel germline APC gene mutation in a large familial adenomatous polyposis kindred displaying variable phenotypes. Gut. 1995;36(5):731-6.

38. Debinski HS, Love S, Spigelman AD, Phillips RK. Colorectal polyp counts and cancer risk in familial adenomatous polyposis. Gastroenterology. 1996;110(4):1028-30.

39. Crabtree MD, Fletcher C, Churchman M, Hodgson SV, Neale K, Phillips RK, et al. Analysis of candidate modifier loci for the severity of colonic familia adenomatous polyposis, with evidence for the importance of the $\mathrm{N}$-acetyl transferases. Gut. 2004;53(2):271-6.

40. Lipton L, Tomlinson I. The genetics of FAP and FAP-like syndromes. Fam Cancer. 2006;5(3):221-6. doi:10.1007/s10689-005-5673-3.

41. Nieuwenhuis MH, Vasen HF. Correlations between mutation site in APC and phenotype of familial adenomatous polyposis (FAP): a review of the literature. Crit Rev Oncol Hematol. 2007;61(2):153-61. doi:10.1016/j. critrevonc.2006.07.004.

42. Lynch HT, Watson P. AFAP: variety is the spice of life. Gut. 1998;43(4):451-2.

43. Cetta F, Dhamo A. Inherited multitumoral syndromes including colorectal carcinoma. Surg Oncol. 2007;16 Suppl 1:S17-23. doi:10.1016/j. suronc.2007.10.013.
44. Wachsmannova-Matelova L, Stevurkova V, Adamcikova Z, Holec V, Zajac V. Different phenotype manifestation of familial adenomatous polyposis in families with APC mutation at codon 1309. Neoplasma. 2009;56(6):486-9.

45. Houlston R, Crabtree M, Phillips R, Tomlinson I. Explaining differences in the severity of familial adenomatous polyposis and the search for modifier genes. Gut. 2001;48(1):1-5.

46. Bertario L, Russo A, Sala P, Varesco L, Giarola M, Mondini P, et al. Multiple approach to the exploration of genotype-phenotype correlations in familial adenomatous polyposis. J Clin Oncol. 2003;21(9):1698-707. doi:10.1200/JCO. 2003.09.118.

47. Kwong LN, Dove WF. APC and its modifiers in colon cancer. Adv Exp Med Biol. 2009;656:85-106.

48. Cormier RT, Dove WF. Dnmt1N/+ reduces the net growth rate and multiplicity of intestinal adenomas in C57BL/6-multiple intestinal neoplasia (Min)/+ mice independently of p53 but demonstrates strong synergy with the modifier of Min 1(AKR) resistance allele. Cancer Res. 2000;60(14):3965-70.

49. Nimmrich I, Friedl W, Kruse R, Pietsch S, Hentsch S, Deuter R, et al. Loss of the PLA2G2A gene in a sporadic colorectal tumor of a patient with a PLA2G2A germline mutation and absence of PLA2G2A germline alterations in patients with FAP. Hum Genet. 1997;100(3-4):345-9.

50. Tomlinson IP, Beck NE, Neale K, Bodmer WF. Variants at the secretory phospholipase A2 (PLA2G2A) locus: analysis of associations with familial adenomatous polyposis and sporadic colorectal tumours. Ann Hum Genet. 1996;60(Pt 5):369-76.

51. McCart AE, Vickaryous NK, Silver A. Apc mice: models, modifiers and mutants. Pathol Res Pract. 2008;204(7):479-90. doi:10.1016/j.prp.2008.03.004.

52. Otterpohl KL, Gould KA. Genetic dissection of the Mom5 modifier locus and evaluation of Mom5 candidate genes. Mamm Genome. 2015;26(5-6):23547. doi:10.1007/s00335-015-9567-x.

53. Van Nieuwenhuysen T, Naert T, Tran HT, Van Imschoot G, Geurs S, Sanders E, et al. TALEN-mediated apc mutation in Xenopus tropicalis phenocopies familial adenomatous polyposis. Oncoscience. 2015;2(5):555-66.

54. Short E, Thomas LE, Hurley J, Jose S, Sampson JR. Inherited predisposition to colorectal cancer: towards a more complete picture. J Med Genet. 2015; 52(12):791-6. doi:10.1136/jmedgenet-2015-103298.

55. Talseth-Palmer BA, Brenne IS, Ashton KA, Evans TJ, McPhillips M, Groombridge C, et al. Colorectal cancer susceptibility loci on chromosome $8 \mathrm{q} 23.3$ and $11 \mathrm{q} 23.1$ as modifiers for disease expression in lynch syndrome. J Med Genet. 2011;48(4):279-84.

56. Wijnen JT, Brohet RM, van Eijk R, Jagmohan-Changur S, Middeldorp A, Tops CM, et al. Chromosome 8q23.3 and 11q23.1 variants modify colorectal cancer risk in Lynch syndrome. Gastroenterology. 2009;136(1):131-7.

57. Ghorbanoghli Z, Nieuwenhuis MH, Houwing-Duistermaat JJ, JagmohanChangur S, Hes FJ, Tops CM et al. Colorectal cancer risk variants at 8q23.3 and 11q23.1 are associated with disease phenotype in APC mutation carriers. Fam Cancer. 2016. doi:10.1007/s10689-016-9877-5.

58. Jaeger E, Webb E, Howarth K, Carvajal-Carmona L, Rowan A, Broderick $P$, et al. Common genetic variants at the CRAC1 (HMPS) locus on chromosome 15q13.3 influence colorectal cancer risk. Nat Genet. 2008; 40(1):26-8.

59. Tenesa A, Farrington SM, Prendergast JG, Porteous ME, Walker M, Haq N, et al. Genome-wide association scan identifies a colorectal cancer susceptibility locus on 11q23 and replicates risk loci at 8q24 and 18q21. Nat Genet. 2008; 40(5):631-7.

60. Tomlinson IP, Webb E, Carvajal-Carmona L, Broderick P, Howarth K, Pittman AM, et al. A genome-wide association study identifies colorectal cancer susceptibility loci on chromosomes 10p14 and 8q23.3. Nat Genet. 2008; 40(5):623-30.

61. Broderick P, Carvajal-Carmona L, Pittman AM, Webb E, Howarth K, Rowan A, et al. A genome-wide association study shows that common alleles of SMAD7 influence colorectal cancer risk. Nat Genet. 2007;39(11):1315-7.

62. Houlston RS, Cheadle J, Dobbins SE, Tenesa A, Jones AM, Howarth K, et al. Meta-analysis of three genome-wide association studies identifies susceptibility loci for colorectal cancer at 1q41, 3q26.2, 12 q13.13 and $20 q 13$. 33. Nat Genet. 2010;42(11):973-7. doi:10.1038/ng.670.

63. Houlston RS, Webb E, Broderick P, Pittman AM, Di Bernardo MC, Lubbe S, et al. Meta-analysis of genome-wide association data identifies four new susceptibility loci for colorectal cancer. Nat Genet. 2008;40(12):1426-35. doi: 10.1038/ng.262.

64. Crabtree MD, Tomlinson IP, Talbot IC, Phillips RK. Variability in the severity of colonic disease in familial adenomatous polyposis results from differences 
in tumour initiation rather than progression and depends relatively little on patient age. Gut. 2001;49(4):540-3.

65. Crabtree MD, Tomlinson IP, Hodgson SV, Neale K, Phillips RK, Houlston RS. Explaining variation in familial adenomatous polyposis: relationship between genotype and phenotype and evidence for modifier genes. Gut. 2002:51(3):420-3.

66. Dietrich WF, Lander ES, Smith JS, Moser AR, Gould KA, Luongo C, et al. Genetic identification of Mom-1, a major modifier locus affecting Mininduced intestinal neoplasia in the mouse. Cell. 1993;75(4):631-9.

67. Ballhausen WG. Genetic testing for familial adenomatous polyposis. Ann N Y Acad Sci. 2000;910:36-47. discussion -9.

68. Lucci-Cordisco E, Risio M, Venesio T, Genuardi M. The growing complexity of the intestinal polyposis syndromes. Am J Med Genet A. 2013;161A(11): 2777-87. doi:10.1002/ajmg.a.36253.

69. Papp J, Kovacs ME, Matrai Z, Orosz E, Kasler M, Borresen-Dale AL, et al. Contribution of APC and MUTYH mutations to familial adenomatous polyposis susceptibility in Hungary. Fam Cancer. 2016;15(1):85-97. doi:10 1007/s10689-015-9845-5.

70. Lubbe SJ, Di Bernardo MC, Chandler IP, Houlston RS. Clinical implications of the colorectal cancer risk associated with MUTYH mutation. J Clin Oncol. 2009;27(24):3975-80. doi:10.1200/JCO.2008.21.6853.

71. Morak M, Heidenreich B, Keller G, Hampel H, Laner A, de la Chapelle A, et al. Biallelic MUTYH mutations can mimic Lynch syndrome. Eur J Hum Genet. 2014;22(11):1334-7. doi:10.1038/ejhg.2014.15.

72. Win AK, Reece JC, Dowty JG, Buchanan DD, Clendenning M, Rosty C, et al. Risk of extracolonic cancers for people with biallelic and monoallelic mutations in MUTYH. Int J Cancer. 2016;139(7):1557-63. doi:10.1002/ijc.30197.

73. Weren RD, Ligtenberg MJ, Kets CM, de Voer RM, Verwiel ET, Spruijt L, et al. A germline homozygous mutation in the base-excision repair gene NTHL1 causes adenomatous polyposis and colorectal cancer. Nat Genet. 2015;47(6): 668-71. doi:10.1038/ng.3287.

74. Kuiper RP, Hoogerbrugge N. NTHL1 defines novel cancer syndrome. Oncotarget. 2015;6(33):34069-70. 10.18632/oncotarget.5864.

75. Rivera B, Castellsague E, Bah I, van Kempen LC, Foulkes WD. Biallelic NTHL Mutations in a Woman with Multiple Primary Tumors. N Engl J Med. 2015; 373(20):1985-6. doi:10.1056/NEJMc1506878.

76. Palles C, Cazier JB, Howarth KM, Domingo E, Jones AM, Broderick P, et al. Germline mutations affecting the proofreading domains of POLE and POLD1 predispose to colorectal adenomas and carcinomas. Nat Genet. 2013;45(2):136-44. doi:10.1038/ng.2503.

77. Church JM. Polymerase proofreading-associated polyposis: a new, dominantly inherited syndrome of hereditary colorectal cancer predisposition. Dis Colon Rectum. 2014;57(3):396-7. doi:10.1097/DCR. 0000000000000084

78. Heitzer E, Tomlinson I. Replicative DNA polymerase mutations in cancer. Curr Opin Genet Dev. 2014;24:107-13. doi:10.1016/j.gde.2013.12.005.

79. Rashid M, Fischer A, Wilson CH, Tiffen J, Rust AG, Stevens P, et al. Adenoma development in familial adenomatous polyposis and MUTYH-associated polyposis: somatic landscape and driver genes. J Pathol. 2016;238(1):98-108. doi:10.1002/path.4643.

80. Rohlin A, Zagoras T, Nilsson S, Lundstam U, Wahlstrom J, Hulten L, et al. A mutation in POLE predisposing to a multi-tumour phenotype. Int J Oncol. 2014;45(1):77-81. doi:10.3892/ijo.2014.2410.

81. Nicolas E, Golemis EA, Arora S. POLD1: Central mediator of DNA replication and repair, and implication in cancer and other pathologies. Gene. 2016; 590(1):128-41. doi:10.1016/j.gene.2016.06.031.

82. Hansen MF, Johansen J, Bjornevoll I, Sylvander AE, Steinsbekk KS, Saetrom P, et al. A novel POLE mutation associated with cancers of colon, pancreas, ovaries and small intestine. Fam Cancer. 2015;14(3):437-48. doi:10.1007/s10689-015-9803-2.

83. Wimmer K, Beilken A, Nustede R, Ripperger T, Lamottke B, Ure B, et al. A novel germline POLE mutation causes an early onset cancer prone syndrome mimicking constitutional mismatch repair deficiency. Fam Cancer. 2017;16(1):67-71. doi:10.1007/s10689-016-9925-1.

84. Spier I, Kerick M, Drichel D, Horpaopan S, Altmuller J, Laner A et al. Exome sequencing identifies potential novel candidate genes in patients with unexplained colorectal adenomatous polyposis. Fam Cancer. 2016. doi:10. 1007/s10689-016-9870-z.

85. Aceto GM, Fantini F, De lure S, Di Nicola M, Palka G, Valanzano R, et al. Correlation between mutations and mRNA expression of APC and MUTYH genes: new insight into hereditary colorectal polyposis predisposition. J Exp Clin Cancer Res. 2015;34:131. doi:10.1186/s13046-015-0244-4.

\section{Submit your next manuscript to BioMed Central and we will help you at every step:}

- We accept pre-submission inquiries

- Our selector tool helps you to find the most relevant journal

- We provide round the clock customer support

- Convenient online submission

- Thorough peer review

- Inclusion in PubMed and all major indexing services

- Maximum visibility for your research

Submit your manuscript at www.biomedcentral.com/submit 